\title{
DISSOLUTION BEHAVIOR, STABILITY AND ANTI-INFLAMMATORY ACTIVITY OF KETOPROFEN COATED TRIPOLYPHOSPHATE MODIFIED CHITOSAN NANOPARTICLE
}

\author{
Jaya Hardi ${ }^{1}$, Purwantiningsih Sugita ${ }^{2, *}$, and Laksmi Ambarsari ${ }^{3}$ \\ ${ }^{1}$ Chemistry Department, Science and Mathematic Faculty of Tadulako University, \\ Bumi Tadulako Tondo Campus, Palu Sulawesi Tengah 94111, Indonesia \\ ${ }^{2}$ Chemistry Department, Science and Mathematic Faculty, Bogor Agricultural University, Fapet Building W2 Lt 4-5, \\ Jl Agatis Kampus IPB Darmaga Bogor 16680, Indonesia \\ ${ }^{3}$ Biochemistry Department, Science and Mathematic Faculty, Bogor Agricultural University, Fapet Building W5 Lt 5 \\ JI Agatis Kampus IPB Darmaga Bogor 16680, Indonesia
}

Received December 17, 2012; Accepted June 24, 2013

\begin{abstract}
Ketoprofen coated tripolyphosphate modified chitosan nanoparticle was resulted from ionic gelation process by ultrasonication, centrifugation, and spray dry methods. Particle was analyzed by particle Size Analyzer. Dissolution and stability of them have conducted by Row Hansen methods at $37 \pm 0.5{ }^{\circ} \mathrm{C}$ and $150 \mathrm{rpm}$ and using climatic chamber at $40 \pm 2{ }^{\circ} \mathrm{C}$ and relative humidity $75 \pm 5 \%$ for 3 months, respectively. Anti-inflammatory activities have conducted by Plate Reader methods. The result showed that B formulae have particles diameter of $563.1 \pm 157.5 \mathrm{~nm}$ and entrapment efficiency of $89.663 \%$, respectively. Dissolution behavior showed that ketoprofen restrained released within acid medium and maximum released within base medium of $11.35-15.87 \%$ and $45.73-99.25 \%$, respectively. Kinetically, dissolution of ketoprofen within intestinal and gastric $\mathrm{pH}$ condition was Korsmeyers-Peppas kinetic models. While, stability behavior showed that B formula has ketoprofen percentage left in nanocapsule after 3 months greater than $90 \%$ with water content and shelf life of $19.68 \%$, and 14.19 week, respectively, and degradation kinetic model followed Avrami-Eroveef equation. Anti-inflammation test showed that B formula had the COX-2 inhibitory activity of $90.86 \%$ is higher than free ketoprofen.
\end{abstract}

Keywords: nanoparticles; ketoprofen; dissolution; stabilities; anti-inflammatory

\section{ABSTRAK}

Ketoprofen tersalut nanopartikel kitosan termodifikasi natrium tripoliposfat (STPP) telah dihasilkan melalui proses gelasi ionic dengan metode ultrasonikasi, sentrifugasi dan dikeringkan dengan metode spray dry. Ukuran partikel dianalisis dengan alat Particle Size Analizer (PSA), sedangkan perilaku disolusi dan stabilitas sediaan dilakukan berturut-turut dengan metode Row Hansen pada suhu $(37 \pm 0.5)^{\circ} \mathrm{C}$ dengan kecepatan pengadukan 150 rpm dan metode climatic chamber pada suhu $40 \pm 2{ }^{\circ} \mathrm{C}$ dengan kelembaban relative $75 \pm 5 \%$ selama 3 bulan. Aktivitas anti-inflamasi sediaan dilakukan dengan metode Plate Reader. Hasil penelitian menunjukkan bahwa formula $B$

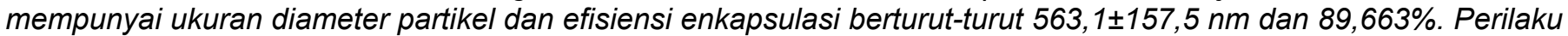
disolusi menunjukkan bahwa ketoprofen lepas terkendali di medium asam dan lepas maksimum di medium basa dengan persentase pelepasan berturut-turut 11,35-15,87\% dan 45,73-99,25\% dan mekanisme kinetikanya di kedua medium tersebut mengikuti model kinetika Korsmeyers-Peppas. Perilaku stabilitas menunjukkan bahwa formula $B$ adalah formula yang mampu mempertahankan kadar ketoprofen lebih dari 90\% dengan kadar air dan usia guna berturut-turut 19,68\%, dan 14,19 minggu dan model kinetika degradasinya mengikuti model Avrami-Eroveef. Hasil analisis anti-inflamasi menunjukkan bahwa formula B menghambat aktivitas COX-2 lebih tinggi (90,86\%) dibandingkan ketoprofen tanpa salut.

Kata Kunci: nanopartikel; ketoprofen; disolusi; stabilitas; anti-inflamasi

\section{INTRODUCTION}

The use of ultrasonic waves in the nanoparticles formation is one of the effective methods. Ultrasonic frequency of $20 \mathrm{kHz}-1 \mathrm{MHz}$ is widely used in chemistry.

* Corresponding author. Tel/Fax : +62-251-8624567

Email address : atiek_ps@yahoo.com
It is called as sonochemistry. Sonochemistry principle is closely linked to the acoustic cavitation phenomenon which is the formation, growth, and rupture of bubbles formed in the liquid medium [1]. On this cavitation phenomenon, the ultrasonic sound that propagates in

Jaya Hardi et al. 
the liquid medium has the ability to generate a bubble or cavity in a liquid medium. When the ultrasonic wave propagates in a liquid medium strain and density cycle occurred. The decrease of pressure resulted in a strain that form a bubble will absorb energy from ultrasonic waves, so the bubble can expand to a maximum size and eventually rupture [2]. According to Schroeder et al. [1] bubble burst resulted extreme conditions which include temperature rising, reaches $5000 \mathrm{~K}$ and pressures increasing up to $1000 \mathrm{~atm}$ with heating to cooling speed reached $>10^{10} \mathrm{~K} / \mathrm{s}$. These extreme conditions cause the termination of the chemical bond, called as the Hot Spot Theory.

Nakorn [3] produce chitosan nanoparticles with a size of $39-300 \mathrm{~nm}$ using ultrasonication method at a frequency of $20 \mathrm{kHz}$ for $5 \mathrm{~min}$, followed by centrifugation for $15 \mathrm{~min}$ at $6000 \mathrm{G}$. Saha et al. [4] produce chitosan nanoparticles with a size of 200-500 nm using ultrasonication method at a frequency of $20 \mathrm{kHz}$ for $20 \mathrm{~min}$, followed by centrifugation at a speed of 15000 rpm for $10 \mathrm{~min}$. Sugita et al. [5] have conducted optimization of chitosan nanoparticle loaded ketoprofen. At ultrasonication conditions with a frequency of $20 \mathrm{kHz}$ ultrasonication every $25 \mathrm{~mL}$ for $60 \mathrm{~min}$ at $20 \%$ amplitude that followed with centrifugation at $19000 \mathrm{rpm}$ for $2 \mathrm{~h}$ at $4{ }^{\circ} \mathrm{C}$ produced chitosan-TPP nanoparticles loaded ketoprofen having average-sized of 222-366 nm with polydispersity index close to $100 \%$. Similarly, the efficiency of ketoprofen adsorption also increased to $87.36 \%$. Adsorption of ketoprofen coated chitosan-STPP nanoparticle has been evidenced by FTIR spectra. Specific peaks at $1410 \mathrm{~cm}^{-1}$ and $1637 \mathrm{~cm}^{-1}$ are from ketoprofen groups. Peaks at $1410 \mathrm{~cm}^{-1}$ was showed electrostatic interaction between carboxylic groups of ketoprofen with amino groups of chitosan. Specific peak also appear at $1153 \mathrm{~cm}^{-1}$ that showed $\mathrm{P}=\mathrm{O}$ group of TPP [6-7]. However, the effectiveness of the preparation of ketoprofen coated chitosan-STPP nanoparticle have not been investigated for its dissolution, stability and activity as an anti-inflammatory property. Study related those properties of ketoprofen loaded chitosan nanoparticles have not been reported previously.

Dissolution test intended to see the drug release kinetics that can describe the release mechanism of that drug. Nanocapsule dissolution test was carried out by using the Hansen paddle method. Sugita et al. [6-7] was conducted dissolution test of chitosan-alginate microparticles with glutaraldehyde as crosslinker loaded with ketoprofen and the result shows that the chitosan microparticles are capable of withstanding the release rate of ketoprofen in acidic medium up to $10.69 \%$ and in alkaline medium up to $99 \%$. The kinetic study followed diffusion mechanism of Hixson-Crowell kinetic models. Stability is defined as the ability of a product to survive within the time limit set during the period of storage and use. The function of a drug is to provide treatment effect, so that the most important thing from a drug is the availability of the active compound thet required until its expired date. Latifah et al. [8] did a stability test based on water and ketoprofen content that were still coated with chitosan nanoparticles using accelerated test period for 3 months at ambient temperature $40 \pm 5{ }^{\circ} \mathrm{C}$ and relative humidity $(\mathrm{RH}) 70 \pm 5 \%$. The test results showed that the availability of chitosan-alginate microcapsules had higher remaining water and ketoprofen content in the microcapsules, respectively, $27-40 \%$ and ketoprofen content more than $90 \%$ of the initial level by 14 weeks. Meanwhile, in vitro antiinflammatory test of ketoprofen coated chitosan nanoparticles intended to illustrate the ability of the active ingredient in inhibiting prostaglandin synthesis. Prostaglandins are inflammatory that being synthesized by the help of cyclooxygenase-2 (COX-2). Ketoprofen works by blocking the cyclooxygenase-2 [9]. Lu et al. [9] conducted inflammatory activity test of ketoprofen that were adsorbed in $\beta$-cyclodextrin complex with antiinflammatory activity of $62.79 \%$, greater than conventional ketoprofen (40.38\%).

Tripolyphosphate modified chitosan nanoparticles offers a hope for improving the performance of activities of anti-inflammatory of ketoprofen. The negative effects of the ketoprofen in the conventional form can be addressed immediately. Therefore, the study of the dissolution behavior, stability, and in vitro anti-inflammatory activity of ketoprofen loaded chitosan nanoparticles is necessary and very important. This research aims to determine its kinetic through in vitro dissolution behavior in acidic medium $\mathrm{pH} 1.2(\mathrm{pH}$ resembles to the stomach environment) and alkaline medium $\mathrm{pH} 7.4(\mathrm{pH}$ resembled to the intestines environment), the stability of the stocks based on the water content and the levels of ketoprofen that still coated with chitosan nanoparticles through the accelerated test period time for 3 months and its in vitro anti-inflammatory activity. The research had conducted either on ketoprofen coated nanoparticles tripolyphosphate modified chitosan or in the form of conventional.

\section{EXPERIMENTAL SECTION}

\section{Materials}

The materials used in this study were include Brata chem commercial chitosan (water content 9.94\%, ash content $0.61 \%$, the degree of deacetylation (DD) $77.26 \%$ and a molecular weight $300319.40 \mathrm{~g} / \mathrm{mol}$ ), sodium tripolyphosphate (STPP), $2 \%$ acetic acid(v/v), 96\% technical ethanol, oleic acid pa, ketoprofen, phosphate buffer solution $\mathrm{pH} 7.2$ and 7.4 , chloride

Jaya Hardi et al. 
buffer $\mathrm{pH}$ 1.2, silica gel, tris- $\mathrm{HCl}$ buffer, heme, arachidonic acid, the enzyme cyclooxygenase-2 (COX-2), tetramethyl-p-phenylenediamine (TMPD), dimethylsulfoxide (DMSO), filter paper, and deionized water.

\section{Instrumentation}

The instruments used in this study are include analytical balance, magnetic stirrer, IKA Werke T8 homogenizer Probe, oven Memmert, Turbidimeter type 2100P, Ultraviolet-Visible spectrophotometer type UV-1700 type Pharma Spec, high intensity ultrasonic processor Cole Palmer 130 watts $20 \mathrm{kHz}$ probe type CV18, Particle Size Analizer (PSA) Delsa Nano C, high speed refrigerated centrifuge Himag CR 21G, Buchi spray drier 190, dissolution tester Logan UDT-804, SPclimatic chamber Firlabo BPEHF, shaking bath Grant, plate reader and $\mathrm{pH}$ meter Beckman 34.

\section{Procedure}

\section{Chitosan nanoparticle synthesis [5]}

Ketoprofen loaded chitosan nanoparticles was prepared by mixing STPP, chitosan, and oleic acid. The formula used was the three formulas used by Sugita et al. [5], the formula B with concentrations of chitosan and oleic acid respectively $2.5 \%(\mathrm{w} / \mathrm{v})$ and $0.8 \mathrm{mg} / \mathrm{mL})$, the formula $A$ with chitosan $2.5 \%(\mathrm{w} / \mathrm{v})$ and oleic acid $0.1 \mathrm{mg} / \mathrm{mL}$, and the formula $P$ with chitosan $3 \%(\mathrm{w} / \mathrm{v})$ oleic acid and $1.5 \mathrm{mg} / \mathrm{mL}$. Each formula was mixed with $0.8 \mathrm{mg} / \mathrm{mL}$ STPP and $0.2 \mathrm{mg} / \mathrm{mL}$ ketoprofen.

A total of $100 \mathrm{~mL}$ of chitosan solution was added to $40 \mathrm{~mL}$ of STPP solution, the mixture was stirred until homogeneous. Furthermore, to the mixture was added $40 \mathrm{~mL}$ ketoprofen and $20 \mathrm{~mL}$ of oleic acid solution with stirring at room temperature. Then, every $25 \mathrm{~mL}$ of the mixture flowed ultrasonic waves at a frequency of $20 \mathrm{kHz}$ and amplitude of $20 \%$ for 60 minutes. Furthermore, the solution centrifuged at 19,000 rpm for 2 hours. Supernatant obtained in the form of nanoparticles suspensions. Changing the form of a powder suspension done by using hair spray. Size of chitosan nanoparticles was analyzed by PSA, while the efficiency was determined by adsorption UV spectrophotometer.

\section{In vitro dissolution test of ketoprofen coated with chitosan nanoparticle [10]}

Nanocapsule dissolution test was carried out by using second type tool (Hansen paddle method). A total of $500 \mathrm{mg}$ nanocapsule were weighed and put into a chamber containing $500 \mathrm{~mL}$ of dissolution medium solution. Dissolution test was carried out in the medium of $\mathrm{pH} 1.2$ (artificial gastric fluid) for three hours and the medium pH 7.4 (artificial intestinal fluid) for six hours at a temperature $37 \pm 0.5{ }^{\circ} \mathrm{C}$ with a stirring speed of $150 \mathrm{rpm}$. Aliquot on acid or alkaline dissolution was taken every $15 \mathrm{~min}$ with a volume of $15 \mathrm{~mL}$ for each sampling. Each time taking aliquots, drawn medium volume was replaced with fresh medium solution with the same volume and temperature. The concentration of ketoprofen in solution aliquot was measured using UV-Vis spectrophotometer. The data obtained were examined by the model kinetics order with 0 order, the first order, Higuchi, Hixson-Crowell, and KorsmeyerPeppas. The curve with the coefficient of determination $\left(R^{2}\right)$ indicates the highest model of the exact release mechanism and release rate constants of the line equation $(k)$ of the drug was determined.

\section{Drug Release Kinetics [12-13]}

Generally, drug release kinetic is controlled with oreder 0 and 1 . Order 0 reaction can be described as:

$[A]_{t}=[A]_{o}-k t$ or $Q=k t$

with $[A]_{t}$ is trace drug concentration in drug dosage after $t,[A]_{0}$ is initial drug concentration, $Q$ is the release percentage, and $k$ is rate efficient. While order 1 reaction is describe as:

$\ln [A]_{t}=\ln [A]_{0}-k t$

Drug release from initial dosage can take place with erosion or diffusion mechanism. On the mechanism of erosion, eroded so that the drug dosage apart when in contact with the liquid medium. The mechanism of drug release by erosion following the Fick's first law derived from the order one of this reaction:

$\frac{d W}{d t}=\frac{D S\left[C_{s}-C\right]}{h}$

with $\frac{d W}{d t}$ is dissolution mass rate, Sis the barrier surface area, $D$ is diffusion coefficient, $C_{\mathrm{s}}$ is drug concentration in saturation state, $C$ is drug concentration in the medium. $H$ is the membrane thickness, and $t$ is the time. The diffusion process is commonly seen in drug dosage using coating and expressed by Higuchi equation, which was developed from Fick's law:

$Q=k t^{1 / 2}$

Besides Higuchi model, the diffusion release can be described also by kinetic modeling approach proposed by Korsmeyer-Peppas through this equation (5):

$Q=k t^{n}$

$Q$ is the fraction of drug released at $t$ time, $k$ is the rate coefficient, and $n$ is the release exponent. The release of the drug can be described through erosion kinetics model approach by Hixson through the equation below: $Q_{0}^{1 / 3}-Q_{t}^{1 / 3}=k t$

Jaya Hardi et al. 
Table 1. Amount of nanoparticle, polydispersity index (IP), and adsorption efficiency (EP) based on material concentration and final turbidity $(\mathrm{Tb})$

\begin{tabular}{|c|c|c|c|c|c|c|c|c|}
\hline \multirow[b]{2}{*}{ Formula } & \multicolumn{2}{|c|}{ Concentration* } & \multirow[b]{2}{*}{$\begin{array}{c}\mathrm{Tb} \\
\text { (NTU) }\end{array}$} & \multirow[b]{2}{*}{$\begin{array}{c}E \\
\text { (Joule) }\end{array}$} & \multirow[b]{2}{*}{$\begin{array}{c}\text { Particle average } \\
\text { diameter }(\mathrm{nm})\end{array}$} & \multirow[b]{2}{*}{$\begin{array}{c}\sum N P \\
(\%)\end{array}$} & \multirow[b]{2}{*}{ IP } & \multirow[b]{2}{*}{ EP (\%) } \\
\hline & $\begin{array}{c}\mathrm{C} \\
(\% \mathrm{~b} / \mathrm{v})\end{array}$ & $\begin{array}{c}\mathrm{AO} \\
(\mathrm{mg} / \mathrm{mL})\end{array}$ & & & & & & \\
\hline$B$ & 2.5 & 0.8 & 70.53 & 9135 & $563.1 \pm 157.5$ & 97.30 & 0.42 & 89.66 \\
\hline A & 2.5 & 0.1 & 31.33 & 8951 & $605.8 \pm 173.0$ & 96.40 & 0.32 & 83.05 \\
\hline $\mathrm{P}$ & 3.0 & 1.5 & 115.25 & 9200 & $1164.9 \pm 327.1$ & 33.50 & 0.22 & 76.56 \\
\hline
\end{tabular}

at $20 \%$ amplitude. $\mathrm{NP}=$ nanoparticle, $\mathrm{IP}=$ polydispersity index, $\mathrm{EP}=$ entrapment efficiency

$Q_{t}$ is the amount of drug released at $t$ time, $Q_{0}$ is the initial amount of drug in the dosage, and $k$ is the rate coefficient.

\section{Stability test of ketoprofen coated with chitosan nanoparticle [13]}

Each nanocapsule formula packed into capsules, 1 capsule contains as much as $100 \mathrm{mg}$. Each nanocapsule formula that has been incorporated into 12 packed brown bottle size $100 \mathrm{~mL}$ and observed for 12 weeks. Each bottle is filled with the capsule from each formula. Then the bottle is stored in a climatic chamber at a temperature $40 \pm 2{ }^{\circ} \mathrm{C}$ and $\mathrm{RH} 75 \pm 5 \%$ for 3 months. Microcapsules stability test conducted chemically and physically. Chemical testing is done by measuring the levels of ketoprofen using spectrophotometry, while the physical stability test is done by measuring the gravimetric water content. Using the second test will be obtained water content and concentration of ketoprofen data in nanocapsule each week over a period of 3 months, which is then used to determine the kinetics of chemical stability and age of the nanocapsule. The kinetics are determined by the stability equation approach followed the general equation model of the reaction kinetics on a solid phase condition (Prout-Tompkins and Avrami-Erofeev) resulting by using differential equation (7) with $l=0, m=1$ and $n$ value was varied

$\frac{d_{x}}{d_{t}}=k x^{l}(1-x)^{m} t^{n}$

\section{In vitro anti inflammatory activity test of ketoprofen coated with chitosan nanoparticle [16]}

A total of $160 \mathrm{~mL}$ tris- $\mathrm{HCl}$ buffer and $10 \mathrm{~mL}$ heme put into three well as the background well. Tris- $\mathrm{HCl}$ buffer $150 \mathrm{~mL}$, heme $10 \mathrm{~mL}, 10 \mathrm{~mL}$ and an enzyme entered in three Initial well as $100 \%$ activity well. Tris- $\mathrm{HCl}$ buffer $150 \mathrm{~mL}, 10 \mathrm{~mL}$ heme, enzyme $10 \mathrm{~mL}$, and $10 \mathrm{~mL}$ of the test sample, put in inhibitor well. Solvent (DMSO) $10 \mathrm{~mL}$ was added to $100 \%$ initial activity wells and background wells. Plate shuffled a few seconds and incubated for five min at $25{ }^{\circ} \mathrm{C}$. Colorimetric substrate solution (TMPD) $20 \mathrm{~mL}$ incorporated into all well used. $20 \mathrm{~mL}$ arachidonic acid incorporated in all well used. Plate again shaken for a few sec and then incubated again for five min at $25^{\circ} \mathrm{C}$. The same treatment is also done for ketoprofen without coating. Absorbance readings made at $590 \mathrm{~nm}$ using a plate reader. Background well absorbance values as $100 \%$ of the initial activity of each sample wells and the inhibitors well are averaged, and then do the following calculation:

$\%$ inhibition =

"A 100\% initial wells corrected - A inhibitor wells corrected" $\times 100 \%$ "A $100 \%$ initial wells corrected"

\section{RESULT AND DISCUSSION}

\section{A, B and P Formula Properties}

Ultrasonication principles closely linked to the acoustic cavitation phenomenon, the formation, growth, and rupture of bubbles formed in the liquid medium [1]. When the ultrasonic wave propagates in a liquid medium strain and density cycles occur, bubbles formed will absorb energy and ultrasonic waved, so the bubble will expand to its maximum size and eventually rupture [2]. The outbreak of the bubble causes the particle size becomes smaller, and also followed by the falling value of the turbidity. Turbidity is the cloudiness of a fluid medium level with Nephelometric Turbidity Units (NTU). Turbidity of initial formulas A, B and P measured at 58.7-176.8 NTU, after ultrasonication turbidity measured at $52.5-144.8$ NTU. This is supported by the physical appearance of the color of the solution changes to be clearer than the initial color. Treatment continued to produce the supernatant by centrifugation at 31.33-115.25 NTU turbidity value. Decreasing in turbidity values indicate that the ultrasonication and centrifugation can reduce the particle size of a solution.

PSA analysis results indicate that the formula B has a particle size of $563.1 \pm 157.5 \mathrm{~nm}$ with polydispersity index (IP) 0.42 . it is lower than the formula $A$ and $P$ with consecutive sizes $605.8 \pm 173.0 \mathrm{~nm}$ and $1164.9 \pm 327.1 \mathrm{~nm}$ respectively with IP value of $0: 32$ and 0:22 (Table 1). Polydispersity index is a measure of the particle size distribution width. Uniformity of size was indicated by the value of IP should be equal or lower than 0.3. Based on IP data, 
formulas $A$ and $P$ is more uniform in size compare to the formula $B$, but based on particle size formulas $A$ and $B$ are in the category of nano-sized particles, $10-1000 \mathrm{~nm}$ [17] and the second formula has a percentage of nanoparticles size over $95 \%$ compared to formula $\mathrm{P}$. Uniformity of size and the high number seen in the role of nano particles adsorb ketoprofen were analyzed through the measurement of the adsorption efficiency (EP). Formula $B$ has a higher EP than formula $A$ and $P$. EP formula $B$ is also higher than the results of Sugita et al. [5] research by using the same method. The EP is also higher than EP rivastigmin coated with chitosan nanoparticles modified with STPP [18]. This study shows consistent results from Sugita et al. [5] studies, formula $B$ is a formula with physical properties better than formula $A$ and $P$, but all of three formulas can be developed further as a candidate for ketoprofen drug coating.

\section{Dissolution Behavior of A, B and P Formula}

Dissolution test is useful to describe the relevant mechanisms of drug release kinetics from a matrix. The test is performed in vitro using two media as a representative medium resembling human gastric $(\mathrm{pH}$ 1.2) and intestinal medium $(\mathrm{pH}$ 7.4). Drug release mechanism very influenced by $\mathrm{pH}$ factor. Ionic crosslinking of chitosan-STPP could be through swelling on acid and base medium. The bond density of chitosanSTPP will be decrease on acid and base medium until the drugs released [14]. The release process of ketoprofen coated chitosan modified with STPP from time to time are presented in Fig. 1 and the total concentration of ketoprofen is released after treatment in both acidic and alkaline medium that are presented in Table 2.

Fig. 1 shows the curve of time effect on the average release of ketoprofen on artificial medium for the stomach and intestines. In the first 15 to $30 \mathrm{~min}$ in the acid medium, a formula that is able to with stand the rate of release of ketoprofen from the matrix is the $P$ formula, then followed with $B$ and $A$ formula. Furthermore, the release rate of ketoprofen after $30 \mathrm{~min}$ apart slowly and under control. This is shown by the large concentrations of ketoprofen that were released up to that time of $180 \mathrm{~min}$, the $P$ formula is lower than the $A$ and $B$ formula (Table 2). However, the ability of the third formulas in controlling the release of ketoprofen in acid medium less favorable than that of ketoprofen microparticles coated chitosan-alginate crosslinked with glutaraldehyde [6-7], but still better than the chitosan$\mathrm{CMC}$ and chitosan-guar gum that were also crosslinked with glutaraldehyde [19] and Li et al. [20] who observed nifedipine drug release coated chitosan-alginate nanoparticles, even better than ketoprofen without a salute.

Meanwhile, the first 15 to $45 \mathrm{~min}$ in alkaline medium, the formula that can liberate ketoprofen close to $100 \%$ is a formula $\mathrm{B}$, then followed with formula $\mathrm{P}$ around $92 \%$, the formula $A$ is only $50 \%$, and the release rate of ketoprofen over $90 \%$ for a new formula achieved in the 90 min. Formula A, B and P along with the results of Sugita et al. [6-7] that coated ketoprofen with chitosan-alginate microparticles crosslinked with glutaraldehyde. Modified chitosan matrix formulations were not a barrier to the release of ketoprofen in alkaline medium, because the medium is destroyed and ketoprofen released similarly with ketoprofen without coating. Performance of modified chitosan in alkaline medium as coating is better than hydroxymethyl propyl cellulose in coated the same drug, which is ketoprofen [21].

Release behavior of ketoprofen gel matrix modified chitosan crosslinked with STPP controlled by diffusion processes, as it was ever done to the matrix of chitosan-CMC [19], and chitosan alginate [6-7] with glutaraldehyde as crosslinker. Sutriyo et al. [22] reveals that if a hydrated matrix can last a long time in a certain time, then the rate of drug release is controlled by diffusion and linear release pattern with the root of time. Conversely, if a hydrated matrix can not survive long in a certain time, then the rate of drug release is controlled by erosion events and patterns of linear release with time. Sugita et al. [12] reported that the test results of the membrane diffusion of ketoprofen coated by chitosan-guar crosslinked with glutaraldehyde through a mechanism that begins with the swelling of the membrane when the membrane in contact with the fluid, then the formation and opening of the pore membrane so that the drugs can pass through the matrix .The thicker the layer of gel that must be passed by ketoprofen, the greater the barrier that must be ketoprofen overcome for migration [23]. Chitosanalginate membrane with a thickness of 10-34 $\mu \mathrm{m}$ successfully passed ketoprofen dose of 50 and $75 \mathrm{mg} / \mathrm{L}$ both at 37 and $42{ }^{\circ} \mathrm{C}$. Concentration of ketoprofen in the recipient cell at equilibrium (Cs) at therapeutic concentrations approaching those conditions, $15-25 \mathrm{mg} / \mathrm{L}$. The time needed to reach the value associated with the $C s$ parameter which are concentrations of ketoprofen (A), the diffusion temperature $(T)$, and the membrane thickness $(h)$ ranged between 3.33 and $12.5 \mathrm{~h}$. This suggests that the chitosan-alginate coating potential for ketoprofen sustained release dosage so that the frequency of administration of ketoprofen can be minimized and may reduce the side effects from the use of ketoprofen [23].

Dissolution test data is used to investigate the release kinetics. The parameters include the order of the

Jaya Hardi et al. 
Table 2. Ketoprofen percentage that being measured from in vitro dissolution test after $3 \mathrm{~h}$ in acid medium and after $6 \mathrm{~h}$ in basic medium

\begin{tabular}{ccc}
\hline \multirow{2}{*}{ Formula } & Ketoprofen release in the medium (\%) \\
\cline { 2 - 3 } & Acid & Basic \\
\hline B & 15.87 & 99.25 \\
A & 17.38 & 94.96 \\
P & 13.76 & 92.80 \\
Ketoprofen without coating & 43.28 & 94.77 \\
\hline
\end{tabular}

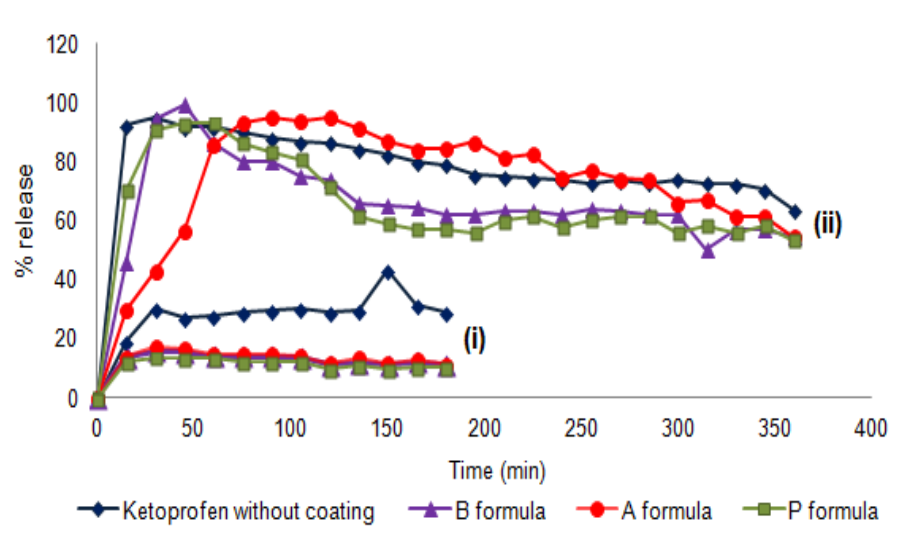

Fig 1. Effect of time against ketoprofen release rate in acid medium (i) and basic medium (ii)

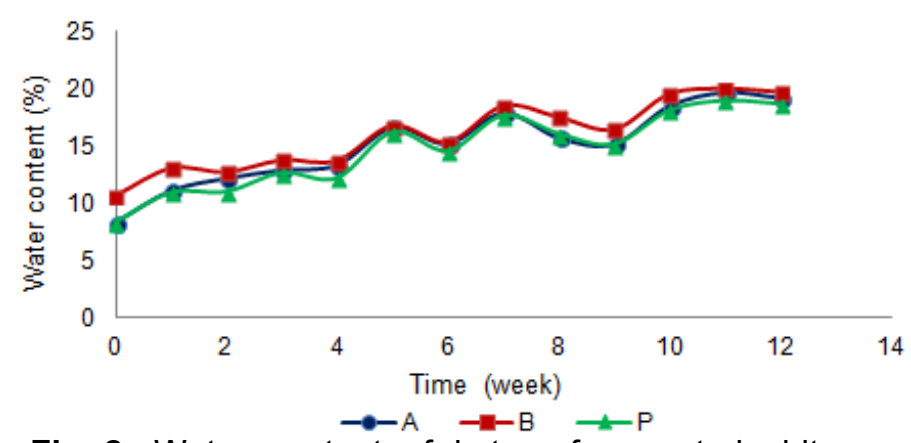

Fig 2. Water content of ketoprofen coated chitosanSTPP nanoparticle each week

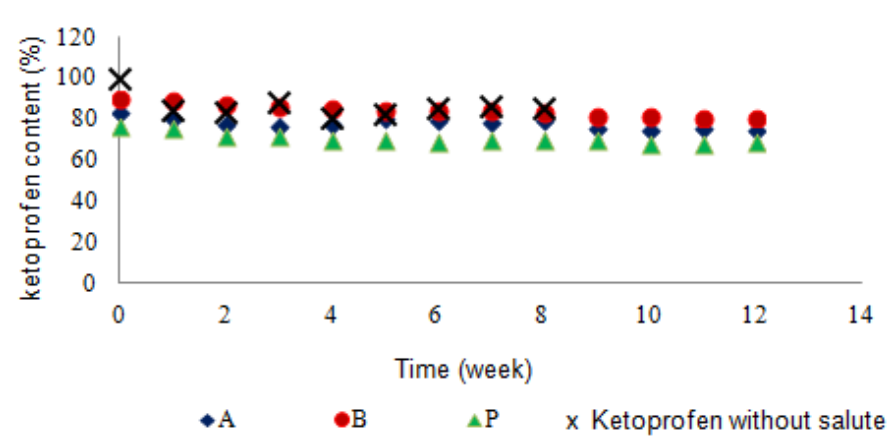

Fig 3. Total ketoprofen remaining in chitosan-STPP nanoparticle each week

reaction, the value of $k$ and $t_{1 / 2}$ of ketoprofen. Determination of the reaction order is done using graphical methods, namely by looking at the value of the coefficient of determination, $R^{2}$ curves derived from the relationship between the concentration of ketoprofen and time [12-13]. The three formulas show the release kinetics of ketoprofen in both acidic and alkaline medium, all formulas followed Korsmeyer-Peppas kinetics model. The coefficient of determination $\left(R^{2}\right)$, the highest in both acidic and alkaline medium is achieved by the formula $B$ with a rate constant of release $(k)$ respectively $2.113 \mathrm{~mol}^{2} \mathrm{~L}^{-2} \mathrm{~min}^{-1}$ and 1.499 $\mathrm{mol}^{2} \mathrm{~L}^{-2} \mathrm{~min}^{-1}$. Likewise with ketoprofen without coating, its kinetic also follows Korsmeyer-Peppas models. Mechanism of Korsmeyer-Peppas kinetic models indicate that the drug regard less of the matrix is dominated by the diffusion process. The study is in line with research conducted by Sugita et al. [6-7], Shoaib et al. [11], Kim et al. [24], and Sarvanan et al. [12], but different from chitosan-alginate crosslinked with glutaraldehyde a mechanism in acid medium is dominated by the first order, whereas in alkaline medium it follow order-0 and Hixson-Crowell. Release mechanism shown by the first and zero order equation support through the mechanism of drug release process of erosion, while the Hixson-Crowell equation signifies apart by drug diffusion mechanism accompanied by erosion events [6].

\section{Stability and Shelf Life of A, B and P Formula}

The stability of nanoparticle filled with ketoprofen evaluated from two aspects, which are the physical and chemical stability for three months of testing. Physical stability was determined by measuring the dosage of water content. The recommended water content for pharmaceutical products is less than 10\% [25]. The stability of the chemical dosage is determined by determining the levels of drugs that are still coated in the matrix after three months of testing. The nature of the coating is categorized either when it is still able to maintain drug levels over $90 \%$ [13].

Fig. 2 shows the relationship between the water content at the time of observation for 3 months. In general, the average water content of the three formulas rose with increasing storage time. Use extreme humidity climatic chamber causing water levels rise and is also supported by the nature of the product is hygroscopic (water absorbing nature). Initial 
Table 3. Ketoprofen degradation in stability test for three months

\begin{tabular}{clccccc}
\hline Formula & Kinetic reaction model & Rate equation & $R^{2}$ & {$[\mathrm{~A}]_{\mathrm{o}}{ }^{\mathrm{a}}(\%)$} & {$[\mathrm{A}]_{12}{ }^{\mathrm{b}}(\%)$} & {$[\mathrm{A}]_{\mathrm{t}}^{\mathrm{c}}(\%)$} \\
\hline $\mathrm{B}$ & Avrami-Erofeev, $\mathrm{n}=1$ & $\mathrm{y}=0.0079 \mathrm{x}+0.015$ & 0.96 & 89.66 & 81.00 & 90.34 \\
$\mathrm{~A}$ & Avrami-Erofeev, $\mathrm{n}=4$ & $\mathrm{y}=3 \times 10^{-6} \mathrm{x}+0,031$ & 0.55 & 83.05 & 75.14 & 90.48 \\
$\mathrm{P}$ & The order of the pseudo-1 & $\mathrm{y}=2 \times 10^{-6} \mathrm{x}+9 \times 10^{-5}$ & 0.74 & 76.56 & 69.38 & 90.63 \\
\hline
\end{tabular}

Description: ${ }^{a}$ ketoprofen initial content, ${ }^{b}$ ketoprofen content within two 12 weeks, ${ }^{c}$ ketoprofen content that still coated after 12 weeks

Table 4. Best formula order based on shelf life and water content

\begin{tabular}{ccccccc}
\hline Formula & $\begin{array}{c}\text { Shelf life } \\
\text { (week) }\end{array}$ & $\begin{array}{c}\text { Weight value } \\
\text { based on shelf life }\end{array}$ & $\begin{array}{c}\text { Water } \\
\text { content (\%) }\end{array}$ & $\begin{array}{c}\text { Weight value based } \\
\text { on water content }\end{array}$ & $\begin{array}{c}\text { Weight total } \\
\text { value }\end{array}$ & $\begin{array}{c}\text { Change of }(\Delta) \\
\text { Water content }(\%)\end{array}$ \\
\hline B & 14.19 & 1 & 19.68 & 3 & 4 & 9.08 \\
A & 12.83 & 2 & 19.22 & 2 & 4 & 10.92 \\
P & 10.01 & 3 & 18.65 & 1 & 4 & 10.35 \\
\hline
\end{tabular}

water content of formula $\mathrm{A}, \mathrm{B}$, and $\mathrm{P}$, respectively 8.3 , 10.6 and $8.3 \%$, and after 12 weeks of storage moisture third consecutive formula is $19: 22,19.68$ and $18.65 \%$. The water content is still better when compared with that of ketoprofen microparticles coated with chitosanalginate [8] and chitosan-guar gum [13] that both crosslinked with glutaraldehyde under the same conditions. Although the water content of the formula B showed highest moisture after a 12-week storage period, but the change range is lower than the formula $A$ and $P$. This shows that the formula $B$ matrix formulation that can with stand interaction with water vapor that is expected to prevent the hydrolysis reaction in the active compound. The difference in water levels rise in the third formula is suspected because of the thickness, density matrix and IP.

Fig. 3 shows the relationship between the levels of ketoprofen that were still coated in the matrix after the storage time for 12 weeks. In general, the levels of the active compound in the preparation of the third formula was decrease with increasing storage time. Loss of ketoprofen on coated stocks less than ketoprofen without coating. Ketoprofen levels without coating on the first week fell to $15 \%$, higher than the coated ketoprofen, that only decrease about $0.11-2.47 \%$ levels initially. Initial concentrations of ketoprofen $(\% \mathrm{w} / \mathrm{w})$ were over laid on the formula A, B and F, respectively, 83.048, 89.663 and $76.556 \%$, and after storage for 12 weeks, ketoprofen concentration (\% $\mathrm{w} / \mathrm{w})$ remaining in the third matrix formula is $75.14,81.00$ and $69.38 \%$, respectively. All three formulas have a similar range of reduction, and the levels of coated ketoprofen during the storage period of 12 weeks is still over $90 \%$ from the initial level (Table 3 ). This indicates that the chemical stability of the three formulas are eligible [13]. In this study, the stability matrix of chitosan-STPP in protecting ketoprofen is less favorable than the complex (hydroxymethyl propyl cellulose) -(sodium carboxymethyl cellulose) that coated ranitidine hydrochloride[26], but it's better than the solid form tetrahydrokannabinol (THC) [27] both measured by the same method with this study.
Data content of ketoprofen per week may be used for the determination of the decomposition reaction kinetics model of drug dosage. By knowing its kinetic model, then the value of drug degradation rate constant (k) can be used to determine age for the expired time. Reaction kinetics model for the third formula is based on the regression curve between concentration and time with the highest $R^{2}$ value. The approach relies drug decomposition kinetics model of the expired time, solution or solid form. Based on the highest $R^{2}$ value, a formula $\mathrm{B}, \mathrm{A}$, and $\mathrm{P}$ each following drug degradation reaction kinetics model Avrami-Erofeev $(n=1)$, AvramiErofeev $(n=4)$, and the order of the pseudo-1 (Table 3), and formula $\mathrm{B} R^{2}$ value is more than $90 \%$. AvramiErofeev kinetics model $(n=1)$ was known as the firstorder kinetics in the degradation mechanisms of solid dosage forms. Avrami-Erofeev kinetic model equations describing the chemical drug degradation reactions in the solid conditions allegedly caused by autocatalytic reaction controlled by the formation and growth of reactions nuclei with various modifications [15]. The kinetics of the solid reaction conditions have a more complex model than the kinetic model of reaction in solution conditions, because the reaction occurs in heterogeneous systems. Many theories have been developed, but not as improved as model theory of reaction kinetics in solution conditions, so the study is limited to the estimation of the selected corresponding kinetics model.

Third test formula showed that it can last for 10 until 14 weeks (Table 4). Formula $B$ has the longest age (14.19 weeks) compared to formula $A$ and $P$ which last for 12.83 weeks and 10.01 weeks respectively. This formula age is still better than the chitosanalginate microparticles crosslinked with glutaraldehyde [8]. Nevertheless, this is not the only aspect that is reviewed to determine the feasibility of a drug dosage. In this study, the best formula for determining the feasibility of using a weighting based on the data for age and moisture content. Age weighting was done with the sort of formula to the value of age for the

Jaya Hardi et al. 
longest to the shortest. In contrast, the water content is done by weighting formula to sort lowest to highest water content. The total value of the smallest weight is the best nanoparticle formula. If there are two or more values of the same weight, the more dominant factor for age. Weights between the three formulas are the same, but the age order of formula $B$ is longer than $A$ and $P$. Range of change in the amount of $(\Delta)$ formula $B$ water content $(9.08 \%)$ is also smaller than the formula $A$ (10.92\%) and $P(10.35 \%)$. Therefore, the best formula represented by the formula $B$ followed by formula $A$ and $P$. Based on the dissolution behavior and stability of nanoparticle-STPP coated ketoprofen, then the formula $B$ is the composition of nanoparticles that consistently gives the best results.

\section{Anti Inflammatory Activity of B Formula}

The aim of this test is to see if the ketoprofen coating using ultrasonication where the preparation was exposed to high temperature was capable to act as an anti inflammatory agent. Formula B anti inflammatory activity was analyzed based on its ability to inhibit the enzyme cyclooxygenase-2 (COX-2) that plays a role in synthesizing prostaglandins as the cause of inflammation. The ability ofCOX-2 inhibition is shown by the lower absorbance of the sample solution compared to the blank solution using the plate reader measurement. Colors are formed in solution due oxidation of tetramethyl-p-phenylenediamine (TMPD) to release one electron that form a colored compound that absorbat $590 \mathrm{~nm}$ wavelength. TMPD oxidized simultaneously with changes prostaglandin $\mathrm{G}_{2}\left(\mathrm{PGG}_{2}\right)$ to prostaglandin $\mathrm{H}_{2}\left(\mathrm{PGH}_{2}\right)$ by the peroxidase activity of COX. When COX (especially COX-2) inhibited by inhibitor the conversion of $\mathrm{PGG}_{2}$ to $\mathrm{PGH}_{2}$ did not happen and therefore oxidation TMPD to form colored compounds will not happen too.

Ketoprofen concentration being used for anti inflammatory activity assay was $5.95 \mathrm{mg} / \mathrm{L}$ to $500 \mathrm{mg}$ of nanoparticles. At that concentration, formula $B$ is able to inhibit the enzyme COX-2 by $91 \%$, slightly higher than conventional ketoprofen that approaches $88 \%$ at the same dosage of ketoprofen. This value is consistent with Saha et al. [4] research that tested the antimicrobial activity of ampicillin trihydrate drug coated chitosanSTPP nanoparticles. Ampicillin trihydrate nanoparticle formula gave $14 \mathrm{~mm}$ inhibition zone higher than the conventional form which is only about $12 \mathrm{~mm}$ after $48 \mathrm{~h}$. The results of this study indicate that the ultrasonication process does not damage the compounds, it even still able to produce high activity. Excellence form chitosanSTPP nanoparticles loaded with ketoprofen will reduce the COX-2 enzyme much longer than conventional forms. As reported by Lu et al. [9] through an in vivo animal model with rats. Research results report that the anti-inflammatory activity of ketoprofen that were absorbed in $\beta$-cyclodextrin complex is higher $(63 \%)$ than conventional ketoprofen that were only $40 \%$.

\section{CONCLUSION}

Formula B with composition of chitosan nanoparticles was $2.5 \%(\mathrm{w} / \mathrm{v})$, ketoprofen $0.2 \mathrm{mg} / \mathrm{mL}$, sodium tripolyphosphate $0.84 \mathrm{mg} / \mathrm{mL}$, and oleic acid $0.8 \mathrm{mg} / \mathrm{mL}$ yielded an average particle diameter of $563.1 \pm 157.5 \mathrm{~nm}$. Dissolution behavior in acidic medium able to control the release of ketoprofen up to $180 \mathrm{~min}$ only $15.87 \%$ loss, followed Korsmeyer-Peppas kinetics model, while its stability behavior showed ketoprofen percentage left in nanocapsule after 3 months, water content and shelf life of $90.34 \%, 19.68 \%$, and 14.19 weeks, respectively, with degradation kinetic model followed Avrami-Eroveef. Formula B has the ability of COX-2 inhibition $91 \%$, slightly higher than conventional ketoprofen that giving $88 \%$ of the inhibition at the same dosage of ketoprofen.

\section{REFERENCES}

1. Schroeder, A., Kost, J., and Barenholz, Y., 2009, Chem. Phys. Lipids, 162, 1-2, 1-16.

2. Hielscher, T., 2005, Ultrasonic production of nanosize dispersions and emulsions, in: Proceedings of European Nanosystems Conference ENS'05 Paris, France, 14-16 December 2005.

3. Nakorn, P.N., 2008, J. Met. Mater. Miner., 18 2, 73-77.

4. Saha, P., Goyal, A.K., and Rath, G., 2010, Trop. J. Pharm. Res., 9, 5, 483-488.

5. Sugita, P., Ambarsari, L., and Farichah, F., 2013, Int. J. Res. Rev. Appl. Sci., 14, 3, 612-618.

6. Sugita P., Ambarsari L., Sari Y.A., and Nugraha Y. 2013. Int. J. Res. Rev. Appl. Sci., 14, 1, 141-149.

7. Sugita, P., Napthaleni, Kurniati, M., and Wukirsari T., 2010, Makara Sci. Ser., 14, 1, 107-112.

8. Latifah, S., Sugita, P., and Srijanto, B., 2010, Stabilitas mikrokapsul ketoprofen tersalut kitosanalginat, in Prosiding Seminar Nasional Sains III; Fakultas MIPA Institut Pertanian Bogor, 13 November 2010, 248-259.

9. Lu, W-L., Zhang, Q., Zheng, L., Wang, H., Li, R-Y., Zhang, L-F., Shen, W-B., and Tu, X-D., 2004, Biol. Pharm. Bull., 27, 10, 1515-1520.

10. Departemen Kesehatan RI, 1995, Farmakope Indonesia, Ed. Ke-4, Jakarta.

11. Shoaib, M.H., Tazeen, J., Merchant, H.A., and Yousuf, R.I., 2006, J. Pharm. Sci., 19, 2, 119-124.

12. Sarvanan, M., Nataraj, K.S., and Ganesh, K.S., 2007, Chem. Pharm. Bull., 51, 8, 978-983.

Jaya Hardi et al. 
13. Sugita, P., Srijanto, B., Arifin, B., and Setyowati, E.V., 2009, Indo. J. Chem., 9, 3, 391-397.

14. Berger, J., Reist, M., Mayera, J.M., Felt, O., and Gurny, R., 2004, Eur. J. Pharm. Biopharm., 57, 1, 35-52.

15. Levenspiel, O., 1999, Chemical Reaction Engineering, $3^{\text {rd }}$ ed., John Wiley \& Sons, New York.

16. Cayman Chemical Company, 2002, Colorimetric COX ovine inhibitor screening assay, kit no. 760111. USA.

17. Patel, J.K., and Jivani N.P., 2009, Int. J. Pharm. Sci. Nanotechnol., 2, 2, 517-522.

18. Kaur, S.P., Rao, R., Hussain, A., and Khatkar, S., 2011, J. Pharm. Sci. Res., 3, 5, 1227-1232.

19. Sugita, P., Achmadi, S.S., and Yundhana, Y., 2010, J. Nat. Indonesia, 13, 1, 21-26.

20. Li, P., Dai, Y-N, Zhang, J-P, Wang, A-Q., and Wei, Q., 2008, Int. J. Biomed. Sci., 4, 3, 221-228.
21. Najmuddin, M., Ahmed, A., Shelar, S., Patel, V., and Khan, T., 2010, Int. J. Pharm. Pharm. Sci., 2, 2, 164-168.

22. Sutriyo, Joshita, D., and Rosari, I., 2005, Majalah Ilmu Kefarmasian, 2, 3,145-153.

23. Sugita, P., Asnel, R.S., Arifin, B., and Wukirsari, T., 2010, Indo. J. Chem., 10, 3, 269-275.

24. Kim, M-S., Kim, J-S., and Hwang, S-J., 2007, Chem. Pharm. Bull., 55, 11, 1631-1634.

25. Menteri Kesehatan, 1994, Keputusan Menteri Kesehatan Republik Indonesia Nomor: 661/MENKES/SKNII/1994 Tentang persyaratan obat tradisional, Jakarta.

26. Janardhan, D., Llingam, M., Mohan, C.K., and Venkateswarlu, V., 2008, Int. J. Pharm. Sci. Nanotechnol., 1, 3, 227-232.

27. van Drooge D.J., Hinrichs, W.L., Dickhoff, B.H., Elli, M.N., Visser, M.R., Zijlstra, G.S., and Frijlink, H.W., 2005, Eur. J. Pharm. Sci., 26, 2, 231-240. 